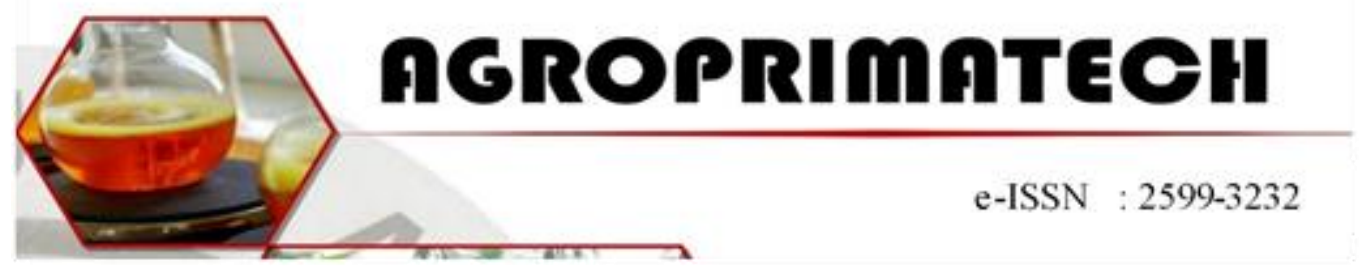

\title{
PENGARUH DOSIS PUPUK CAN DAN KONSENTRASI PUPUK HAYATI CAIR BIOBOST TERHADAP PERTUMBUHAN DAN PRODUKSI TANAMAN PAKCOY (Brassica rapa L)
}

\author{
MARULITUA SIPAYUNG ${ }^{1}$, MERIATY ${ }^{1}$, ALDY ALFARYZY ${ }^{2}$ \\ ${ }^{1}$ Staf Penagajar Program Studi Agroteknologi Fakultas Pertanian USI \\ ${ }^{2}$ Mahasiswa Program Studi Agroteknologi Fakultas Pertanian USI \\ Email: marulituasipayung@gmail.com
}

\begin{abstract}
ABSTRAK
Penelitian ini bertujuan untuk mengetahui Pengaruh dosis pupuk CAN dan konsentrasi pupuk hayati cair Biobost terhadap pertumbuhan dan produksi tanaman paccoy (Brassica rapa L). Penelitian ini dilaksanakan di Desa Bahkapul Kecamatan Siantar Sitalasari, Kota Pematang Siantar. Penelitian ini menggunakan Rancangan Acak Kelompok (RAK) faktorial dengan 2 faktor dan 3 ulangan. Faktor pertama adalah dosis pupuk CAN (C) : $\mathrm{C}_{0}\left(0 \mathrm{gram} / \mathrm{m}^{2}\right), \mathrm{C}_{1}(37$ gram $\left./ \mathrm{m}^{2}\right), C_{2}\left(62 \mathrm{gram} / \mathrm{m}^{2}\right)$, dan $\mathrm{C}_{3}\left(87 \mathrm{gram} / \mathrm{m}^{2}\right)$. Faktor kedua yaitu: Konsentrasi Biobost : $\mathrm{B}_{0} 0 \mathrm{cc} / \mathrm{L}, \mathrm{B}_{1} 10 \mathrm{cc} / \mathrm{L}, \mathrm{B}_{2} 15 \mathrm{cc} / \mathrm{Lr}, \mathrm{B}_{3} 20 \mathrm{cc} / \mathrm{L}$. Parameter yang diamati adalah tinggi tanaman $(\mathrm{cm})$, jumlah daun (helai), berat bersih per tanaman dan (gr) berat tanaman per plot $(\mathrm{kg})$. Hasil penelitian menunjukkan dosis pupuk CAN berpengaruh nyata pada semua parameter pengamatan. Konsentrasi pupuk hayati cair Biobost berpengaruh nyata pada tinggi tanaman, jumlah daun dan berat tanaman per plot kecuali berat bersih pertanaman. Kombinasi perlakuan, pada tinggi tanaman 17 HST dan jumlah daun berpengaruh nyata. Perlakuan dosis pupuk CAN berpengaruh nyata terhadap tinggi tanaman, jumlah daun, berat bersih per tanaman dan berat tanaman per plot.

Kata Kunci: Pupuk, CAN, Biobost, Pakcoy, Konsentrasi
\end{abstract}

\section{PENDAHULUAN}

Pangan merupakan sumber energi bagi manusia, dan makanan tersebut secara langsung atau tidak langsung berasal dari tanaman yang sebagian besar termasuk dalam kelompok sayuran. Sayuran mutlak diperlukan dalam konsumsi masyarakat sehari-hari karena kandungan gizinya, terutama vitamin dan mineral yang dapat mendukung kecukupan gizi masyarakat, sehingga menyebabkan permintaan komoditas sayuran terjadi setiap hari. Hal inilah yang menjadikan komoditas sayuran memiliki peluang yang besar untuk dikembangkan 
Agroprimatech

Vol. 4 No. 2, April 2021

(Rubatzky dan Yamaguchi, 1999 dalam Prawoto, 2012).

Pentingnya sayuran bagi

kesehatan masyarakat memicu peningkatan produk sayuran di Indonesia. Untuk menghasilkan sayuran segar, sehat dan bermutu tinggi, diperlukan penanganan yang baik mulai tahap pemilihan lokasi, benih, hingga cara pemupukannya (Rukmana, 1994). Menurut Sukmawati (2012), budidaya sayuran organik yang paling menguntungkan adalah sayuran daun (leave vegetable) daripada sayuran buah. Hal ini disebabkan teknik pemeliharaan sayuran daun lebih mudah, murah, dapat ditanam dimana saja dan siklus perputaran produksinya cepat

Pakcoy (Brassica rapa L.) adalah tanaman jenis sayuran yang termasuk keluarga Brassicaceae. Tumbuhan pakcoy masih memiliki kerabat dekat dengan sawi, jadi pakcoy dan sawi merupakan satu jenis, hanya varietasnya saja yang berbeda. Penampilannya sangat mirip dengan sawi, akan tetapi lebih pendek dan kompak, tangkai daunnya lebar dan kokoh, tulang daunnya mirip dengan sawi hijau, dan daunnya lebih tebal dari sawi hijau (Edi, 2010).

Ditinjau dari segi ekonomi dan bisnis, pakcoy layak diusahakan untuk memenuhi permintaan konsumen yang cukup tinggi dan peluang pasar internasional yang cukup besar, karena harga jual pakcoy lebih mahal daripada jenis sawi lainnya. Pakcoy digemari oleh masyarakat Indonesia mulai dari masyarakat kelas bawah hingga kelas atas. Rasa dari sayuran ini mudah diterima oleh lidah sehingga sayuran ini berpotensi untuk dikembangkan (Prihmantoro, 2010).

Tanaman pakcoy merupakan sayuran hortikultura yang memiliki
e-ISSN :2599-3232

produksi yang cukup tinggi. Dilihat dari rata-rata produksi di Indonesia sayuran ini masih cukup rendah yaitu 20 ton/ha, dibandingkan negaranegara di Cina 40 ton/ha, Filipina 25 ton/ha, Taiwan 30 ton/ha. Berdasarkan data Badan Pusat Statistik (2014) produksi sayuran pakcoy di Indonesia dari tahun 2010 sampai 2013 sebesar 583.770 ton, 580.969 ton, 594.934 ton dan 600.961 ton. Data tersebut menunjukkan bahwa pada tahun 2011 sempat mengalami penurunan hasil produksi tanaman pakcoy. Salah satu penyebab rendahnya tingkat produktivitas tanaman ini adalah masih sedikitnya ketersediaan varietas unggul yang tahan terhadap penyakit berbahaya seperti busuk lunak dan bercak daun, serta masih sedikit sekali varietas yang tahan terhadap suhu panas (Haryanto dkk, 2012).

Unsur hara merupakan hal yang sangat penting bagi media tanam, ketersediaannya mempengaruhi pertumbuhan tanaman yang berada di atasnya. Pemenuhan unsur hara pada media tanam dilakukan melalui sistem pemupukan. Pemupukan adalah pemberian bahan berupa pupuk atau bahan-bahan lain seperti bahan organik, bahan kapur, pasir ataupun tanah liat ke dalam tanah yang bertujuan untuk menambahkan unsur hara ke dalam tanah (Hasibuan, 2006).

Pupuk digolongkan menjadi dua jenis yaitu pupuk organik dan pupuk anorganik. Pupuk anorganik memiliki kelebihan dalam memenuhi sifat kimia tanah seperti penambahan unsur hara yang tersedia di dalam tanah, tetapi penggunaan pupuk anorganik secara berlebihan akan berdampak terhadap penurunan kualitas tanah dan lingkungan. Salah satu jenis pupuk anorganik yang biasa digunakan dalam budidaya 
Agroprimatech

Vol. 4 No. 2, April 2021

tanaman adalah pupuk CAN (Cantik) Majemuk, Urea, TS, NPK dan lainlain. Pemberian pupuk organik pada tanaman budidaya dapat meningkatkan produktivitas tanah karena bahan organik memiliki kemampuan untuk memperbaiki sifat anorganik, fisika maupun biologi tanah (Suwahyono, 2011).

Pupuk hayati cair Biobost mengandung sejumlah bakteri positif yang berguna untuk tanaman, anti jamur (Trichoderma sp) dan zat pengatur tumbuh. Manfaat pupuk hayati cair Biobost yaitu untuk meningkatkan proses biokimia tanah sehingga menyediakan unsur $\mathrm{N}$ (Nitrogen), unsur P (Phosfor) dan $\mathrm{K}$ (Kalium) yang cukup mudah diserap tanah, memperbaiki struktur tanah sehingga lebih subur dengan menguraikan residu pestisida didalam tanah, mempercepat pertumbuhan sehingga panen lebih cepat, meningkatkan kapasitas penyerapan tanah terhadap udara dan air.

Pemupukan anorganik pada lahan pertanian apabila dilakukan secara terus menerus tanpa diimbangi dengan pemberian pupuk organik dapat mengakibatkan kerusakan tanah baik secara fisik maupun biologi. Permasalahan lainnya adalah adanya opini dari petani bahwa penggunaan pupuk anorganik akan menimbulkan ketergantungan pada proses pertanaman. Oleh karena itu, dosis pupuk anorganik yang digunakan akan selalu meningkat tiap kali panen dan merugikan secara ekonomis. Ketergantungan terhadap pemakaian pupuk anorganik secara perlahan akan diminimalkan dengan penggunaan pupuk hayati yang ramah lingkungan sehingga meningkatkan kesuburan tanah, memacu pertumbuhan tanaman, dan

$$
\text { e-ISSN :2599-3232 }
$$

meningkatkan produksi tanaman Pakcoy.

Pemberian pupuk anorganik berupa CAN memberikan ketersediaan unsur hara makro $\mathrm{Ca}$, dan $\mathrm{N}$ yang dibutuhkan oleh tanaman. Pemberian pupuk organik dapat memperbaiki tekstur tanah dan meningkatkan kesuburan tanah. Menurut Kedekoh dan Amirudin (2007), pemupukan yang ideal adalah apabila unsur hara yang diberikan dapat melengkapi unsur hara yang tersedia menjadi tepat. Oleh karena itu, dengan mempertimbangkan banyaknya manfaat dari pupuk organik cair Biobost dan ditambah dengan pemberian pupuk CAN perlu dilakukan penelitian ini sehingga diketahui pengaruh interaksi pupuk CAN dan pupuk organik cair Biobost terhadap tanaman Pakcoy.

\section{METODE PENELITIAN}

Penelitian ini dilaksanakan di Desa Bahkapul Kecamatan Siantar Sitalasari, Kota Pematang Siantar. Penelitian ini menggunakan Rancangan Acak Kelompok (RAK) faktorial dengan 2 faktor dan 3 ulangan. Faktor pertama adalah dosis pupuk CAN (C) : $\mathrm{C}_{0}(0$ $\left.\mathrm{gram} / \mathrm{m}^{2}\right), C_{1}\left(37 \mathrm{gram} / \mathrm{m}^{2}\right), C_{2}(62$ $\left.\mathrm{gram} / \mathrm{m}^{2}\right)$, dan $\mathrm{C}_{3}\left(87 \mathrm{gram} / \mathrm{m}^{2}\right)$. Dan Konsentrasi Biobost (B): $\mathrm{B}_{0} 0 \mathrm{cc} / \mathrm{L}, \mathrm{B}_{1}$ $10 \mathrm{cc} / \mathrm{L}, B_{2} 15 \mathrm{cc} / \mathrm{Lr}, B_{3} 20 \mathrm{cc} / \mathrm{L}$. Parameter yang diamati adalah tinggi tanaman $(\mathrm{cm})$, jumlah daun (helai), berat bersih per tanaman ( $\mathrm{gr}$ ) berat per plot $(\mathrm{kg})$.

\section{HASIL DAN PEMBAHASAN}

\section{Tinggi Tanaman Pakcoy (cm)umur 10, 17 dan 24 HST. dan Jumlah \\ Daun}

Hasil uji beda rata-rata tinggi tanaman dan jumlah daun Pakcoy 
Agroprimatech

Vol. 4 No. 2, April 2021

e-ISSN : 2599-3232

akibat pemberian dosis pupuk CAN

dan Konsentrasi pupuk Hayati cair

Biobost dapat dilihat pada tabel 1

Tabel 1 : Hasil Uji Beda Rata-Rata Tinggi Tanaman Pakcoy $(\mathrm{cm})$ dan Jumlah daun Akibat Pemberian Dosis Pupuk CAN, Konsentrasi Pupuk Hayati Cair Biobost.

\begin{tabular}{ccccc}
\hline Perlakuan & \multicolumn{3}{c}{ Tinggi Tanaman } & Jumlah Daun \\
& $10 \mathrm{HST}$ & $17 \mathrm{HST}$ & $24 \mathrm{HST}$ & \\
\hline $\mathrm{C}_{0}$ & $6,06 \mathrm{c}$ & $9,18 \mathrm{~b}$ & $12,15 \mathrm{~d}$ & $14,73 \mathrm{~d}$ \\
$\mathrm{C}_{1}$ & $6,79 \mathrm{~b}$ & $10,22 \mathrm{~b}$ & $15,44 \mathrm{c}$ & $18,26 \mathrm{~b}$ \\
$\mathrm{C}_{2}$ & $7,27 \mathrm{a}$ & $12,75 \mathrm{a}$ & $17,11 \mathrm{~b}$ & $17,53 \mathrm{c}$ \\
$\mathrm{C}_{3}$ & $7,36 \mathrm{a}$ & $13,43 \mathrm{a}$ & $19,82 \mathrm{a}$ & $20,19 \mathrm{a}$ \\
\hline $\mathrm{B}_{0}$ & $6,51 \mathrm{c}$ & $10,56 \mathrm{~b}$ & $14,54 \mathrm{~b}$ & $14,93 \mathrm{~d}$ \\
$\mathrm{~B}_{1}$ & $6,80 \mathrm{~b}$ & $10,19 \mathrm{~b}$ & $15,81 \mathrm{ab}$ & $18,42 \mathrm{~b}$ \\
$\mathrm{~B}_{2}$ & $7,14 \mathrm{a}$ & $12,90 \mathrm{a}$ & $17,03 \mathrm{a}$ & $17,67 \mathrm{c}$ \\
$\mathrm{B}_{3}$ & $7,00 \mathrm{ab}$ & $11,92 \mathrm{a}$ & $17,13 \mathrm{a}$ & $19,67 \mathrm{a}$ \\
\hline $\mathrm{C}_{0} \mathrm{~B}_{0}$ & 5,49 & $7,10 \mathrm{f}$ & 9,31 & $11,37 \mathrm{n}$ \\
$\mathrm{C}_{0} \mathrm{~B}_{1}$ & 5,94 & $8,83 \mathrm{ef}$ & 11,73 & $14,03 \mathrm{~m}$ \\
$\mathrm{C}_{0} \mathrm{~B}_{2}$ & 6,39 & $11,40 \mathrm{~cd}$ & 13,46 & $17,93 \mathrm{f}$ \\
$\mathrm{C}_{0} \mathrm{~B}_{3}$ & 6,40 & $9,40 \mathrm{de}$ & 14,10 & $15,57 \mathrm{k}$ \\
$\mathrm{C}_{1} \mathrm{~B}_{0}$ & 6,82 & $9,50 \mathrm{de}$ & 14,28 & 14,771 \\
$\mathrm{C}_{1} \mathrm{~B}_{1}$ & 6,66 & $9,37 \mathrm{de}$ & 15,27 & $22,58 \mathrm{~b}$ \\
$\mathrm{C}_{1} \mathrm{~B}_{2}$ & 7,08 & $9,57 \mathrm{de}$ & 16,16 & $16,40 \mathrm{j}$ \\
$\mathrm{C}_{1} \mathrm{~B}_{3}$ & 6,59 & $12,43 \mathrm{bc}$ & 16,06 & $19,30 \mathrm{~d}$ \\
$\mathrm{C}_{2} \mathrm{~B}_{0}$ & 6,74 & $11,13 \mathrm{~cd}$ & 15,97 & $16,67 \mathrm{i}$ \\
$\mathrm{C}_{2} \mathrm{~B}_{1}$ & 7,14 & $10,67 \mathrm{cde}$ & 17,46 & $17,50 \mathrm{~g}$ \\
$\mathrm{C}_{2} \mathrm{~B}_{2}$ & 7,56 & $14,87 \mathrm{a}$ & 17,07 & $17,17 \mathrm{~h}$ \\
$\mathrm{C}_{2} \mathrm{~B}_{3}$ & 7,63 & $14,33 \mathrm{ab}$ & 17,96 & $18,78 \mathrm{e}$ \\
$\mathrm{C}_{3} \mathrm{~B}_{0}$ & 7,01 & $14,50 \mathrm{ab}$ & 18,61 & $16,93 \mathrm{hi}$ \\
$\mathrm{C}_{3} \mathrm{~B}_{1}$ & 7,49 & $11,90 \mathrm{c}$ & 18,79 & $19,57 \mathrm{c}$ \\
$\mathrm{C}_{3} \mathrm{~B}_{2}$ & 7,57 & $15,77 \mathrm{a}$ & 21,47 & $19,21 \mathrm{de}$ \\
$\mathrm{C}_{3} \mathrm{~B}_{3}$ & 7,39 & $11,53 \mathrm{c}$ & 20,42 & $25,07 \mathrm{a}$ \\
\hline
\end{tabular}

Keterangan: Angka yang diikuti oleh notasi yang tidak sama pada kolom yang sama berbeda nyata pada taraf $5 \%$.

Tabel 1 menunjukkan bahwa perlakuan $\mathrm{C}_{3} \quad$ (CAN $\left.87 \mathrm{~g} / \mathrm{m}^{2}\right)$ menghasilkan tanaman tertinggi umur 10,17 dan 24 HST, diikuti pada perlakuan $\mathrm{C}_{2}, \mathrm{C}_{1}$ dan $\mathrm{C}_{0}$

Dosis CAN terhadap tinggi tanaman pada $10 \mathrm{HST} \mathrm{C}_{0}$ berbeda nyata dengan $\mathrm{C}_{1}, \mathrm{C}_{1}$ berbeda nyata dengan $\mathrm{C}_{2}, \mathrm{C}_{2}$ tidak berbeda nyata dengan $\mathrm{C}_{3}$. Pada $17 \mathrm{HST} \mathrm{C}_{0}$ tidak berbeda nyata dengan $\mathrm{C}_{1}, \mathrm{C}_{1}$ berbeda nyata dengan $\mathrm{C}_{2}$ dan $\mathrm{C}_{3}$. Pada 24 HST $\mathrm{C}_{0}$ berbeda nyata dengan $\mathrm{C}_{1}, \mathrm{C}_{2}$ dan $\mathrm{C}_{3}$.
Pupuk CAN merupakan pupuk majemuk yang mengandung Nitrogen dan Kalsium. Nitrogen yang terkandung di dalamnya berbentuk senyawa Amonium $\left(\mathrm{NH}_{4}{ }^{+}\right)$dan Nitrat $\left(\mathrm{NO}_{3}{ }^{-}\right)$. Menurut Miner (2013) Nitrogen yang berbentuk $\left(\mathrm{NH}_{4}{ }^{+}\right)$ mempunyai keuntungan dalam hal tidak hilangnya dibandingkan dengan $\left(\mathrm{NO}_{3}{ }^{-}\right)$. Selain itu (Sarwono, 2002) menyatakan bahwa senyawa $\left(\mathrm{NH}_{4}{ }^{+}\right)$ merupakan kation tertukar, dapat dipengaruhi oleh koloid tanah, bersifat mobil dalam tanah pasiran 
Agroprimatech

Vol. 4 No. 2, April 2021

tanah yang membuat suasana aerasi yang baik karena yang aktif bakteri aerobik, sedangkan senyawa $\left(\mathrm{NO}_{3}{ }^{-}\right)$ sangat larut air, tidak dapat di pegang koloid tanah, sehingga penggunaan $\left(\mathrm{NH}_{4}{ }^{+}\right)$lebih tinggi di bandingkan $\left(\mathrm{NO}_{3}{ }^{-}\right)$. Jadi nitrogen berpengaruh pada tinggi tanaman sejalan dengan (Dwidjosaputro 1990 dalam Erawan, 2013) unsur $N$ berfungsi dalam pertumbuhan vegetarif tanaman. Nitrogen merupakan unsur hara esensial untuk pembelahan dan perpanjangan sel, Sehingga N merupakan penyusun dalam protoplasma yang banyak terdapat pada titik tumbuh. Fungsi kalsium pada tanaman adalah sebagai pengatur serapan ion, agar pertumbuhan tidak terhambat dan tanaman tidak menjadi kerdil (Kusdianti, 2014).

Tabel 1 menunjukkan bahwa perlakuan $\mathrm{B}_{3}$ (Biobost $20 \mathrm{cc} / \mathrm{L}$ ) menghasilkan tanaman tertinggi di umur $24 \mathrm{HST}$, namun di 10 dan 17 HST tertinggi pada perlakuan $B_{2}$ (Biobost $15 \mathrm{cc} / \mathrm{L}$ ), diikuti semakin pendek pada perlakuan $\mathrm{B}_{2}, \mathrm{~B}_{1}$ dan $\mathrm{B}_{0}$ pada 24 HST.

Konsentrasi pupuk hayati cair Biobost terhadap tinggi tanaman pada $10 \mathrm{HST}, \mathrm{B}_{0}$ berbeda nyata dengan $B_{1}, B_{1}$ berbeda nyata tengan $B_{2}, B_{2}$ tidak berbeda nyata dengan $B_{3}$. Pada $17 \mathrm{HST}, B_{0}$ tidak berbeda nyata dengan $B_{1}$, tetapi berbeda nyata dengan $B_{2}$ dan $B_{3}$. Pada 24 HST, $B_{0}$ tidak berbeda nyata dengan $B_{1}, B_{1}$ tidak berbeda nyata dengan $B_{2}$ dan $\mathrm{B}_{3}$.

Pemberian pupuk hayati cair Biobost dapat mengurangi residu dalam tanah sehingga membuat pupuk cepat diserap oleh tanaman. Hal ini sejalan dengan (Nurhidayat, 2007) yang menyatakan bahwa dalam budidaya sayuran buahbuahan dan tanaman hias, tanaman akan tumbuh dengan baik jika unsur

$$
\text { e-ISSN :2599-3232 }
$$

hara yang dibutuhkan dalam keadaan cukup dan seimbang seperti pemberian pupuk $\mathrm{N}, \mathrm{P}$ dan $\mathrm{K}$ yang berperan aktif pada masa pertumbuhan vegetatif, dan pupuk hayati cair Biobost meningkatkan proses biokimia tanah sehingga mendorong tersedianya unusr $\mathrm{N}, \mathrm{P}$ dan $\mathrm{K}$ yang cukup mudah diserap oleh tanaman.

Tabel 1 menunjukkan bahwa pada umur 10 dan 24 HST interaksi perlakuan tidak berbeda nyata, namun di 17 HST berbeda nyata dan tanaman tertinggi dihasilkan perlakuan $\mathrm{C}_{3} \mathrm{~B}_{2} \quad(15,77 \mathrm{~cm}), \mathrm{C}_{3} \mathrm{~B}_{2}$ tidak berbeda nyata dengan $\mathrm{C}_{2} \mathrm{~B}_{2}$, $\mathrm{C}_{2} \mathrm{~B}_{3}$ dan $\mathrm{C}_{3} \mathrm{~B}_{0}$ pada umur $17 \mathrm{HST}$. Perlakuan $\quad \mathrm{C}_{3} \mathrm{~B}_{2} \quad$ cenderumg menghasilkan tanaman tertinggi $(21,47 \mathrm{~cm})$ di $24 \mathrm{HST}$. Diduga karena hara yang tersedia pada pupuk CAN lebih cepat tersedia dan lebih mudah diserap oleh tanaman karena pengaruh Biobost yang berlaras meningkatkan Kapasitas Tahan Kation (KTC) tanah.

\section{Jumlah Daun Tanaman Pakcoy (helai) \\ Data rata-rata jumlah daun} tanaman pakcoy pada tabel 1 menunjukkan bahwa perlakuan dosis pupuk CAN, konsentrasi pupuk hayati cair Biobost dan interaksi perlakuan pupuk CAN dan pupuk hayati cair Biobost berpengaruh nyata terhadap jumlah daun.

Dari tabel 1 diperoleh perlakuan

$\mathrm{C}_{3}\left(\mathrm{CAN} 87 \mathrm{~g} / \mathrm{m}^{2}\right)$ menghasilkan jumlah

daun tertinggi pada umur $38 \mathrm{HST}$, diikuti pada perlakuan $\mathrm{C}_{1}, \mathrm{C}_{2}$ dan $\mathrm{C}_{0}$.

Dosis CAN terhadap jumlah daun tanaman pada $\mathrm{C}_{0}$ berbeda nyata dengan $\mathrm{C}_{1}, \mathrm{C}_{2}$ dan $\mathrm{C}_{3}$. Dapat di katakan bahwa kandungan nitrogen pada pupuk CAN sangat berperan baik untuk pertumbuhan jumlah daun. Hal ini sejalan dengan 
Agroprimatech

Vol. 4 No. 2, April 2021

e-ISSN :2599-3232

pendapat (Dwidjosaputro 1990 dalam Erawan, 2013) unsur $\mathrm{N}$ berfungsi dalam pertumbuhan vegetarif tanaman. Nitrogen merupakan unsur hara esensial untuk pembelahan dan perpanjangan sel. Sehingga N merupakan penyusun dalam protoplasma yang banyak terdapat pada titik tumbuh. Diimbangi dengan kalsium yang cukup pada tanaman yang menghasilkan tanaman tumbuh dengan optimal.

Tabel 1 menunjukkan bahwa perlakuan $\mathrm{B}_{3} \quad$ (Biobost $20 \mathrm{cc} / \mathrm{L}$ ) menghasilkan jumlah daun tanaman tertinggi di umur 38 HST, diikuti semakin sedikit pada perlakuan $\mathrm{B}_{1}, \mathrm{~B}_{2}$ dan $\mathrm{B}_{0}$.

Konsentrasi pupuk hayati cair Biobost terhadap jumlah daun tanaman pada $\mathrm{B}_{0}$ berbeda nyata dengan $B_{1}, B_{2}$ dan $B_{3}$.

Pupuk hayati cair Biobost berpengaruh nyata terhadap jumlah daun karena meningkatkan dan mengubah proses biokimia tanah sehingga mendorong tersedianya unusr $\mathrm{N}, \mathrm{P}$ dan $\mathrm{K}$ yang cukup dan mudah diserap oleh tanaman yang sangat berperan pada fase vegetatif tanaman.

Interaksi perlakuan $\mathrm{C}_{3} \mathrm{~B}_{3}(\mathrm{CAN}$ $87 \mathrm{~g} / \mathrm{m}^{2}$ dan Biobost $20 \mathrm{cc} / \mathrm{L}$ ) menghasilkan jumlah daun tanaman tertinggi di umur 38 HST, diikuti semakin sedikit pada perlakuan $\mathrm{C}_{1} \mathrm{~B}_{1}, \mathrm{C}_{3} \mathrm{~B}_{1}$ dan $\mathrm{C}_{1} \mathrm{~B}_{3}$.

Konsentrasi pupuk CAN dan pupuk hayati cair Biobost yang menghasilkan daun terbanyak terdapat pada perlakuan $\mathrm{C}_{3} \mathrm{~B}_{3}$ (CAN $87 \mathrm{~g} / \mathrm{m}^{2}$ dan Biobost $20 \mathrm{cc} / \mathrm{L}$ ) yaitu 25,06 helai. Diduga karena unsur hara yang ada pada pupuk CAN lebih cepat tersedia dan lebih mudah diserap oleh tanaman. Penyebab utama adalah mikro organisme secara efektif dapat meningkatkan penyerapan unsur hara makro ataupun mikro, pupuk Biobost juga meningkatkan efesiensi penggunaan pupuk anorganik $50 \%$ sampai $60 \%$, meningkatkan proses biokimia tanaman sehingga unsur N,P dan $\mathrm{K}$ tersedia dalam jumlah yang cukup sehingga mudah diserap oleh tanaman (Manuhuttu dkk, 2014).

\section{Berat bersih Per Tanaman sampel (g),}

Hasil Uji Beda Rata-rata berat bersih per tanaman dan Berat Tanaman Per plot akibat pemberian Dosis Pupuk CAN dan Konsentrasi Pupuk Hayati Cair Biobost dapat dilihat pada tabel 3.

Tabel 2: Hasil Uji Beda Rata-Rata Berat Bersih Per Tanaman Pakcoy (g) Akibat Pengaruh Dosis Pupuk CAN, Konsentrasi Pupuk Hayati Cair Biobost.

\begin{tabular}{ccc}
\hline Perlakuan & Berat Bersih Per Sampel $(\mathrm{g})$ & Berat Tanaman per plot $(\mathrm{kg})$ \\
\hline $\mathrm{C}_{0}$ & $27,42 \mathrm{c}$ & $0,20 \mathrm{~d}$ \\
$\mathrm{C}_{1}$ & $58,94 \mathrm{ba}$ & $0,32 \mathrm{c}$ \\
$\mathrm{C}_{2}$ & $47,66 \mathrm{cb}$ & $0,56 \mathrm{~b}$ \\
$\mathrm{C}_{3}$ & $70,61 \mathrm{a}$ & $1,01 \mathrm{a}$ \\
\hline $\mathrm{B}_{0}$ & $33,08 \mathrm{~b}$ & $0,39 \mathrm{c}$ \\
$\mathrm{B}_{1}$ & $60,44 \mathrm{a}$ & $0,53 \mathrm{~b}$ \\
$\mathrm{~B}_{2}$ & $46,83 \mathrm{ab}$ & $0,66 \mathrm{a}$ \\
$\mathrm{B}_{3}$ & $64,27 \mathrm{a}$ & $0,50 \mathrm{~b}$ \\
\hline $\mathrm{C}_{0} \mathrm{~B}_{0}$ & 5,22 & 0,71 \\
$\mathrm{C}_{0} \mathrm{~B}_{1}$ & 29,22 & 0,15 \\
$\mathrm{C}_{0} \mathrm{~B}_{2}$ & 42,22 & 0,29 \\
$\mathrm{C}_{0} \mathrm{~B}_{3}$ & 33,00 & 0,28 \\
$\mathrm{C}_{1} \mathrm{~B}_{0}$ & 37,89 & 0,20 \\
$\mathrm{C}_{1} \mathrm{~B}_{1}$ & 81,00 & 0,29
\end{tabular}


Agroprimatech

Vol. 4 No. 2, April 2021

e-ISSN :2599-3232

$\begin{array}{lll}\mathrm{C}_{1} \mathrm{~B}_{2} & 34,11 & 0,55 \\ \mathrm{C}_{1} \mathrm{~B}_{3} & 82,78 & 0,25 \\ \mathrm{C}_{2} \mathrm{~B}_{0} & 38,89 & 0,37 \\ \mathrm{C}_{2} \mathrm{~B}_{1} & 50,56 & 0,57 \\ \mathrm{C}_{2} \mathrm{~B}_{2} & 49,54 & 0,75 \\ \mathrm{C}_{2} \mathrm{~B}_{3} & 51,67 & 0,55 \\ \mathrm{C}_{3} \mathrm{~B}_{0} & 50,33 & 0,93 \\ \mathrm{C}_{3} \mathrm{~B}_{1} & 81,00 & 1,12 \\ \mathrm{C}_{3} \mathrm{~B}_{2} & 61,44 & 1,06 \\ \mathrm{C}_{3} \mathrm{~B}_{3} & 89,67 & 0,94\end{array}$

Keterangan : Angka yang diikuti oleh notasi yang tidak sama pada kolom yang sama berbeda nyata pada taraf $5 \%$

Tabel 2 menunjukkan bahwa $\left.\begin{array}{lllll}\text { perlakuan } & \mathrm{C}_{3} & \text { (CAN } & 87 & \mathrm{~g} / \mathrm{m}^{2}\end{array}\right)$ menghasilkan berat bersih per tanaman sampel tertinggi pada saat $38 \mathrm{HST}$, diikuti semakin ringan pada perlakuan $\mathrm{C}_{1}, \mathrm{C}_{2}$ dan $\mathrm{C}_{0}$.

Dosis pupuk CAN terhadap berat bersih tanaman pada $\mathrm{C}_{0}$ berbeda nyata dengan $\mathrm{C}_{1}, \mathrm{C}_{1}$ tidak berbeda nyata dengan $\mathrm{C}_{2}$ dan $\mathrm{C}_{2}$ berbeda nyata dengan $\mathrm{C}_{3}$.

Produksi tnaman sangat di tentukan oleh banyaknya unsur hara yang tersedia dalam tanah yang dapat di serap dan di manfaatkan oleh tanaman. Sejalan dengan (Dwidjosaputro 1990 dalam Erawan 2013) unsur $N$ berfungsi dalam pertumbuhan vegetarif tanaman. Nitrogen merupakan unsur hara esensial untuk pembelahan dan perpanjangan sel. Sehingga N merupakan penyusun dalam protoplasma yang banyak terdapat pada titik tumbuh, Kalsium memiliki peranan dalam pembentukan protein dan pergerakan karbohidrat yaitu mengatur keseimbangan ion dalam tanaman agar tanaman tidak kekurangan ion dan dapat tumbuh secara optimal (Plaster, 1992).

\section{Berat Tanaman Per plot}

Tabel 2 menunjukkan bahwa perlakuan $\mathrm{B}_{3} \quad$ (Biobost $20 \mathrm{cc} / \mathrm{L}$ ) menghasilkan berat bersih tanaman tertinggi pada saat $38 \mathrm{HST}$, diikuti semakin ringan pada perlakuan $\mathrm{B}_{1,} \mathrm{~B}_{2}$ dan $\mathrm{B}_{0}$

Berat bersih per tanaman sampel pada $\mathrm{B} 0$ berbeda nyata dengan $B_{1}, B_{1}$ tidak berbeda nyata dengan $B_{2}$ dan $B 3$ sedangkan $B_{2}$ tidak berbeda nyata dengan $\mathrm{B}_{0}$.

Pupuk Biobost berperan merubah sifat kimia tanah sehingga mampu menyediakan unsur $\mathrm{N}, \mathrm{P}$ dan $K$ yang di butuhkan dalam pembentukan atau pertumbuhan bagian-bagian vegetatif dalam tanaman, seperti daun dan akar sehingga ketersediaan hara yang baik akan membantu proses pertumbuhan pada tanaman.

Tabel 2 menunjukkan bahwa perlakuan $\mathrm{C}_{3} \mathrm{~B}_{3}$ (CAN $87 \mathrm{~g} / \mathrm{m}^{2}$ dan Biobost $20 \mathrm{cc} / \mathrm{L}$ ) menghasilkan berat bersih per tanaman sampel tertinggi di umur 38 HST, diikuti semakin ringan pada perlakuan $\mathrm{C}_{1} \mathrm{~B}_{3}, \mathrm{C}_{1} \mathrm{~B}_{1}$ dan $\mathrm{C}_{3} \mathrm{~B}_{1}$.

Dosis pupuk CAN dan konsentrasi pupuk hayati cair Biobost terhadap berat bersih per tanaman sampel dengan rata- rata tertinggi terdapat pada perlakuan $\mathrm{C}_{3} \mathrm{~B}_{3}\left(\mathrm{CAN} 87 \mathrm{~g} / \mathrm{m}^{2}\right.$ dan Biobost $20 \mathrm{cc} / \mathrm{L}$ ) yaitu 89,67 g.

Hal itu disebabkan karena hara yang tersedia pada pupuk CAN lebih cepat tersedia dan lebih mudah diserap oleh tanaman karena bidang nya berubah secara kimia oleh Biobost. Penyebab utama adalah mikro organisme secara efektif dapat 
Agroprimatech

Vol. 4 No. 2, April 2021

meningkatkan penyerapan unsur hara makro ataupun mikro, pupuk Biobost juga meningkatkan efesiensi penggunaan pupuk anorganik 50\% sampai $60 \%$, meningkatkan proses biokimia tanah sehingga unsur N,P dan $\mathrm{K}$ tersedia dalam jumlah yang cukup agar mudah diserap oleh tanaman (Manuhuttu dkk, 2014).

Tabel 2 menunjukkan bahwa $\left.\begin{array}{lllll}\text { perlakuan } & \mathrm{C}_{3} & \text { (CAN } & 87 & \mathrm{~g} / \mathrm{m}^{2}\end{array}\right)$ menghasilkan berat tanaman per plot tertinggi pada saat $38 \mathrm{HST}$, diikuti semakin ringan pada perlakuan $\mathrm{C}_{2}, \mathrm{C}_{1}$ dan $\mathrm{C}_{0}$.

Dosis pupuk CAN terhadap berat tanaman per plot pada perlakuan $\mathrm{C}_{0}$ berbeda nyata dengan $\mathrm{C}_{1}, \mathrm{C}_{2}$ dan $\mathrm{C}_{3}$.

Terpenuhinya unsur nitrogen dan baiknya penyerapan ion terhadap tanaman, sehingga mendapatkan hasil yang optimal. (Harjadi, 1999) menyatakan bahwa nitrogen diperlukan tanaman untuk merangsang pertumbuhan tanaman terutama batang, cabang dan daun. Nitrogen memacu daun yang berperan sebagai indikator pertumbuhan tanaman dalam proses fotosintesis.

Tabel 2 menunjukkan bahwa perlakuan $\mathrm{B}_{2}$ (Biobost $15 \mathrm{cc} / \mathrm{L}$ ) menghasilkan berat per plot tertinggi pada $38 \mathrm{HST}$, diikuti semakin ringan pada perlakuan $B_{1}, B_{3}$ dan $B_{0}$.

Konsentrasi pupuk hayati cair Biobost pada perlakuan $B_{0}$ berbeda nyata dengan $B_{1}, B_{2}$ dan $B_{3}$.

Penggunaan Biobost untuk biokimia tanah akan membuat tanah subur, kombinasi mikro bakteri dengan pupuk organik dan anorganik dapat meningkatkan produktivitas lahan yang akan meningkatkan produksi tanaman baik kualitas maupun kuantitasnya. Hal ini menunjukkan bahwa pupuk Biobost mampu menyediakan unsur $\mathrm{N}, \mathrm{P}$ dan $\mathrm{K}$ yang di butuhkan dalam pembentukan atau pertumbuhan
e-ISSN : 2599-3232

bagian bagian-bagian vegetatif tanaman, seperti daun dan akar sehingga ketersediaan hara yang tinggi akan membantu proses pertumbuhan dan tanamam.

Tabel 2 menunjukkan bahwa perlakuan $\mathrm{C}_{3} \mathrm{~B}_{1}$ (CAN $87 \mathrm{~g} / \mathrm{m}^{2}$ dan Biobost $10 \mathrm{cc} / \mathrm{L}$ ) menghasilkan berat tanaman per plot tertinggi di umur 38 HST, diikuti semakin ringan pada perlakuan $\mathrm{C}_{3} \mathrm{~B}_{2}, \mathrm{C}_{3} \mathrm{~B}_{0}$ dan $\mathrm{C}_{3} \mathrm{~B}_{3}$.

Berat tanaman per plot dengan rata-rata tertinggi terdapat pada perlakuan $\mathrm{C}_{3} \mathrm{~B}_{1}$ (CAN $87 \mathrm{~g} / \mathrm{m}^{2}$ dan Biobost $10 \mathrm{cc} / \mathrm{L}$ ) yaitu $1,12 \mathrm{~kg}$.

Pupuk CAN lebih cepat tersedia dan lebih mudah diserap oleh tanaman karena bidang nya berubah secara kimia oleh Biobost. Penyebab utama adalah mikro organisme secara efektif dapat meningkatkan penyerapan unsur hara makro ataupun mikro, pupuk Biobost juga meningkatkan efesiensi penggunaan pupuk anorganik $50 \%$ sampai $60 \%$, meningkatkan proses biokimia tanah sehingga unsur N,P dan $\mathrm{K}$ tersedia dalam jumlah yang cukup agar mudah diserap oleh tanaman (Manuhuttu dkk, 2014).

\section{KESIMPULAN}

Berdasarkan hasil penelitian pemberian dosis pupuk CAN dan konsentrasi pupuk hayati cair Biobost terhadap pertumbuhan dan produksi tanaman pakcoy (Brassica rapa L.) dapat disimpulkan :

a. Perlakuan dosis pupuk CAN berpengaruh nyata terhadap tinggi tanaman, jumlah, berat bersih per tanaman dan berat tanaman per pot.Perlakuan C3 menghasilkan tinggi tanaman tertinggi ( $17,03 \mathrm{~cm})$ umur 24 HST, jumlah daun $(20,19$ helai), berat bersih $(70,61 \mathrm{~g})$, Berat Tanaman Perplot (1.01 $\mathrm{kg}$ ) 
Agroprimatech

Vol. 4 No. 2, April 2021

b. Perlakuan konsentrasi pupuk hayati cair Biobost berpengaruh nyata Terhadap tinggi tanaman, jumlah daun, berat per tanaman dan berat per plot.. Perlakuan B3 menghasilkan tanaman tertinggi $(17,03 \mathrm{~cm})$ umur 24 HST, Jumlah Daun (19,67 helai),Berat Bersih $(64,27 \mathrm{~g})$, Berat Tanaman Perplot $(1,60$ kg) pada B3.

c. Perlakuan kombinasi dosis pupuk CAN dan konsentrasi pupuk hayati cair Biobost berpengaruh nyata terhadap jumlah daun. Perlakuan C3B3 menunjukkan Tinggi tanaman tertinggi $(20,24 \mathrm{~cm})$ umur 24 HST, Jumlah daun $(25,27$ helai),Berat bersih $(89,67 \mathrm{~g})$, Berat Tanaman Perplot $(1,12$ $\mathrm{kg}$ )

\section{DAFTAR PUSTAKA}

Edi, (2010). Budidaya Tanaman Sayuran. Jambi : Balai Pengkajian Teknologi Pertanian (BPTP) Jambi.

Erawan Dedi. Wa Ode Yani. Andi Bahrun 2013. Pertumbuhan dan Hasil Tanaman Sawi. Jurnal Agroteknos 3 (1) : 1925.

Hadisuwito dan Sukamto. 2012. Membuat Pupuk Cair. PT. Agro Media Pustaka. Jakarta.

Haryanto, 2012. Pasar dan Permintaan Sayuran. Pemasaran Hasil Usaha Tani dan Dasar Dasar Pemasaran. Jakarta.

Hasibuan, B.E. 2006. Pupuk dan Pemupukan. Universitas Sumatera Utara. Medan.

Kusdianti. 2014. Pendidikan Biologi
e-ISSN :2599-3232

(Daun), (Online). (http://file.upi.edu/Direktorat/ FPMIPA/JUR._PEND._BIOL OGI/196402261989032R. K USDIANTI/HAndout_mortum _2.pdf, diunduh 9 Juni 2016).

Manuhuttu, A. P.,H. Rehatta, dan J.J. G. Kailola. 2014. Pengaruh Konsentrasi Biobost terhadap Peningkatan Produksi Tanaman Selada (Lactuca sativa L.). Agrologia. 3 (1) : Program studi Agroteknologi Jurusan Budidaya Pertanian, Fakultas Pertanian Pattimura

Nurhidayat. 2007. Mengolah Sampah Untuk Pupuk dan Pestisida Organik. Penebar Swadaya. Jakarta.

Prihmantoro, 2010. Hidroponik Sayuran Semusim Untuk Hobi dan Bisnis. Jakarta : Penebar Swadaya

Rubatzky, V. E. dan M. Yamaguchi. 1999. Sayuran Dunia 3 Prinsip, Produksi, dan Gizi. Penerbit ITB. Bandung.

Rukmana, R. 2010. Bertani Petsai dan Sawi . Penerbit Kanisius. Yogyakarta. 57 hal.

Sarwono, H. 2002. Ilmu Tanah. Akademika Pressindo. Jakarta.

Sukmawati, S. 2012. Budidaya pakcoy (Brassica chinensis. L) Secara Organik Dengan Pengaruh Beberapa Jenis Pupuk Organik. Karya IImiah. Politeknik Negeri Lampung. 9 hal.

Suwahyono, U. 2011. Petunjuk Praktis Penggunaan Pupuk Organik Secara Efektif dan Efisien. Penebar Swadaya. Jakarta. 